\title{
Foliar Application of Calcium Chloride Delays Postharvest Ripening of Strawberry
}

\author{
F. Chéour ${ }^{1}$, C. Willemot ${ }^{1,2}$, J. Arul', Y. Desjardins ${ }^{3}$, J. Makhlouf ${ }^{1}$, P.M. Charest ${ }^{3}$, and \\ A. Gosselin ${ }^{3}$ \\ Département de Sciences et Technologies des Aliments, Université Laval, Québec, PQ. G1K 7P4, \\ Canada
}

Additional index words. Fragaria $\times$ ananassa, storage, calcium

\begin{abstract}
Effects of $\mathrm{CaCl}_{2}$ preharvest treatment on postharvest strawberry (Fragaria $\times$ ananassa) ripening and gray mold development were assessed. Two experiments were carried out in 1987 on two sites. In the first experiment, the effects of rate of application of $\mathrm{CaCl}_{2}$ and degree of fruit maturity at treatment were studied with the conventional cultivar Kent. In the second experiment, the influence of concentration and frequency of application of $\mathrm{CaCl}_{2} \mathrm{was}$ investigated with day-neutral 'Tribute'. Calcium treatment caused a significant increase in fruit and leaf Ca contents, which were closely correlated. The degree of fruit maturity at application and the frequency of treatment did not affect Ca concentration in the tissues. Several maturity criteria were measured during fruit storage in air at $4 \mathrm{C}$. Anthocyanin and free-sugar contents and tissue electrical conductivity increased, while titratable acidity and firmness decreased. In both experiments, Ca treatment delayed ripening and gray mold development. The delay increased with increasing Ca concentration.
\end{abstract}

The importance of $\mathrm{Ca}$ in, the regulation of fruit ripening and vegetable maturation is well established (Ferguson, 1984; Poovaiah, 1986). Studies on leaf senescence (Ferguson, 1984; Poovaiah and Leopold, 1973) and fruit ripening (Poovaiah, 1986) show that tissue $\mathrm{Ca}$ content often infuences various senescence characteristics, e.g., protein and chlorophyll content (Poovaiah and Leopold, 1973) or rate of respiration (Bangerth et al., 1972).

Calcium has been applied before and after harvest to prevent physiological disorders and to delay ripening of various fruits (Poovaiah, 1986). Most Ca entering the tissues accumulates in cell walls and membranes that are thought to be sites of its antisenescence action (Glenn et al., 1988). There has been extensive research on the use of $\mathrm{Ca}$ to delay ripening of various fruits (Paliyath et al., 1984; Richardson and Al-Alani, 1982; Tingwa and Young, 1974), but little attention has been given to strawberry, a fruit with a short shelf life and highly susceptible to mold (Eaves and Leefe, 1962; Maas, 1971).

The present study shows that foliar application of $\mathrm{Ca}$ may have beneficial effects on strawberry fruit storage by delaying ripening and development of gray mold (Botrytis cinerea ).

\section{Materials and Methods}

Two experiments were carried out in 1987 using two strawberry cultivars, conventional 'Kent' and day-neutral 'Tribute'. One-year-old plants were treated with $\mathrm{CaCl}_{2}$ by foliar application 3 to 9 days before harvest. In the first experiment, $\mathrm{CaCl}_{2}$ was applied to 'Kent' plants at $0,5,10,15$, or $20 \mathrm{~kg} \cdot \mathrm{ha}^{-1}$ by repeated runs, when the primary fruit were green or pink, i.e., 9 or 3 days before harvest. At harvest, one-fourth to one-half pink secondary fruits were picked. Plants were grown on a St-

Received for publication 13 Apr. 1989. Centre de Recherche et de Développement sur les Aliments de Saint-Hyacinthe publication no. 137. This research was supported by the Conseil des Recherches en Pêches et Agro-alimentaires du Québec. The help of Guylaine Trachy, Xuan Vovan, and Monique Lacroix is gratefully acknowledged. The cost of publishing this paper was defrayed in part by the payment of page charges. Under postal regulations, this paper therefore must be hereby marked advertisement solely to indicate this fact.

'Département de Sciences et Technologies des Aliments.

'Centre de Recherche et de Développement sur les Aliments de Saint-Hyacinthe. ${ }^{3}$ Département de Phytologie.
Nicolas series sandy loam at a spacing of $60 \mathrm{~cm}$ between plants, $1 \mathrm{~m}$ between rows, and $2 \mathrm{~m}$ between plots. They were fertilized according to the recommendations of the Québec Dept. of Agriculture (CPVQ, 1982). Ripening after harvest was assessed by measurement of firmness, electrical conductivity, anthocyanins, free sugars, and titratable acidity, and by visual rating of mold development.

In the second experiment, the influence of the rate of application of $\mathrm{CaCl}_{2}$ and of the frequency of application on postharvest senescence of the fruit was investigated using 'Tribute'. Plants were grown on a Tiny series sandy loam. The layout of the plots was similar to that of Expt. 1. The plants were treated with 0,10 , or $20 \mathrm{~kg} \mathrm{CaCl}_{2} /$ ha one, two, or three times, i.e., 3, 3 and 6 , or 3,6 , and 9 days before harvest. Ripening after harvest was evaluated as in Expt. 1, except that electrical conductivity and anthocyanins were not assayed.

Storage conditions. Immediately after harvest, fruit was precooled and selected for uniformity of size and color (one-fourth to one-half red) and lack of wounding. Berries were stored in polyethylene 26-liter containers under a continuous air stream at $4 \mathrm{C}$ and close to $100 \% \mathrm{RH}$ for 23 ('Tribute') or 28 days ('Kent'). There were 15 lots of 40 strawberries in each container. The composition of the atmosphere in the containers was checked by gas chromatography (model 29; Fisher-Hamilton Gas Partitioned, Ottawa, Ont.).

Calcium determination. Exchangeable $\mathrm{Ca}$ was determined in soil, leaves, and fruits by atomic absorption spectrophotometry. The leaf and fruit samples were dried at $70 \mathrm{C}$ and digested with nitric and perchloric acids (Gaines and Mitchel, 1979). The soil Ca content was determined by the Mehlich 3 analysis method (Mehlich, 1984).

Measurement of senescence criteria. Total anthocyanins were determined as described by Fuleki and Francis (1968). Anthocyanins were extracted from a 10 -g aliquot of 20- to 30-fruit homogenate with acidified methanol. The results were expressed as absorbance $(510 \mathrm{~nm})$ per gram of fresh weight.

Free sugars were determined by refractometry (Bausch and Lomb optical series YB 3301; Bausch and Lomb, Rochester, N.Y.). Results were expressed as percent free sugars.

Titratable organic acids were measured as described by Morris et al. (1985). Ten grams of homogenate from a 20- to 30- 
fruit sample were made up to $100 \mathrm{~g}$ with deionized water and titrated with $0.1 \mathrm{~N} \mathrm{NaOH}$ to $\mathrm{pH}$ 8.1. Results were expressed as percent citric acid (El-Kazzaz et al., 1983).

Electrical conductivity was measured on 10 strawberries in each replicate by means of electrodes $0.5 \mathrm{~cm}$ apart and "embedded $0.4 \mathrm{~cm}$ deep at the tip of the fruit, connected to a conductivity bridge (YSI model 31; Yellow Springs, Ohio).

Texture was determined on 10 strawberries per replicate, as described by Ahmed and Dennison (1972), with an Instron Universal Testing Instrument, model TMS (Instron Canada, Burlington, Ont.). A 0.749 -cm-diameter point was used to compress the strawberries to a depth of $0.4 \mathrm{~cm}$ with a load cell of $20 \mathrm{~N}$. The speeds of crosshead and recorder chart were 2 and 10 $\mathrm{cm} \cdot \mathrm{min}^{-1}$, respectively. Part of the fruit was sliced off to increase the surface of contact with the base. Results were expressed as force (in Newtons).

Mold was estimated visually, using a scale from 0 to 10,10 indicating fruits completely covered with mold. Results are means of 40 strawberries per replicate. At harvest, fruits were placed in petri dishes on SNA medium (Nirenberg, 1981), and the microorganisms were identified. After storage the microorganisms were identified directly on the strawberries.

Data analysis. An analysis of variance of the results was carried out following a split-split-plot factorial design (Snedecor and Cochran, 1957). Homogeneity of variance was verified by means of the standard Bartlett test (Anderson and McLean, 1974). Each treatment was distributed over three randomized blocks. Orthogonal contrasts with one degree of freedom were used to determine the response of "measured characteristics.

\section{Results}

Determination of $\mathrm{Ca}$ in soil, leaves, and fruits. Calcium levels in leaves and fruits, although low, varied significantly in correlation with the soil Ca content (Table 1). Foliar application of $\mathrm{CaCl}_{2}$ caused an increase in $\mathrm{Ca}$ level in leaves and fruits in both -experiments, but more so in the first one $(P \leq 0.01 ; 26 \%$ at $\left.20 \mathrm{~kg} \cdot \mathrm{ha}^{-1}\right)$ than in the second one $\left(P \leq 0.05 ; 13^{\prime} \%\right)$ (Table 2 ). In both experiments, increase in Ca content of leaves and fruits was linearly correlated with the rate of application. Calcium levels in leaves and fruits were closely correlated $(r=$ 0.97 and 0.88 for Expts. 1 and 2, respectively). Neither degree of maturity at application (Expt. 1) nor repeated applications (Expt. 2) influenced the Ca content of the tissues (data not shown). In Expt. 2, repeated applications did not influence the $\mathrm{Ca}$ content of the tissues, but phytotoxicity symptoms were observed on the leaves after the second and third application at 10 and $20 \mathrm{~kg} \cdot \mathrm{ha}^{-1}$.

Effect of Ca treatment on ripening. Anthocyanins increased

Table 1. Mean contents of $\mathrm{Ca}$ in soil (exchangeable $\mathrm{Ca}$ ), leaves, and fruits of control plots for the two experiments with 'Kent' and 'Tribute' strawberries and correlation with soil Ca content.

\begin{tabular}{cccc}
\hline & \multicolumn{3}{c}{ Ca (\% dry wt) $)^{2}$} \\
\cline { 2 - 4 } Expt. & Soil & Leaves & Fruits \\
\hline 1 & $15 \times 10^{-4} \pm 0.0005$ & $1.08 \pm 0.05$ & $0.19 \pm 0.02$ \\
2 & $22 \times 10^{-4} \pm 0.0002$ & $1.43 \pm 0.13$ & $0.31 \pm 0.03$ \\
$\begin{array}{c}\text { Correlation } \\
\text { with soil }\end{array}$ & & & \\
Ca content $(r)$ & --- & $0.71^{*}$ & $0.67^{*}$ \\
\hline
\end{tabular}

${ }^{z}$ Means of nine replicates $\pm S D$.

*Significant at $P=0.05$.
Table 2. Effect of rate of application of $\mathrm{Ca}$ on $\mathrm{Ca}$ content of leaves and fruits in two separate experiments with 'Kent' (Expt. 1) and 'Tribute' (Expt. 2) strawberries.

\begin{tabular}{lll}
\hline \multirow{2}{*}{$\begin{array}{c}\text { Rate of } \\
\text { application } \\
\left(\mathrm{kg} \cdot \mathrm{ha}^{-1}\right)\end{array}$} & \multicolumn{2}{c}{$\mathrm{Ca}(\% \text { dry wt })^{\mathrm{z}}$} \\
\cline { 2 - 3 } Kent & Leaves & Fruits \\
0 & & \\
5 & 1.08 & 0.19 \\
10 & 1.23 & 0.21 \\
15 & 1.18 & 0.20 \\
20 & 1.37 & 0.23 \\
Significance & 1.36 & 0.24 \\
Treatment & & \\
Linear & 0.01 & 0.01 \\
Tribute & 0.01 & 0.01 \\
0 & & 0.31 \\
10 & 1.43 & 0.33 \\
20 & 1.44 & 0.35 \\
Significance & 1.62 & 0.05 \\
Treatment & & 0.05 \\
Linear & 0.05 & \\
\hline
\end{tabular}

${ }^{2}$ Means of six to nine replicates.

during storage under all treatments, especially in the case of the controls (Fig. la; Table 3). Color and rate of $\mathrm{Ca}$ application were linearly correlated. Although the surface of the berries was pink over one-fourth of the area, the amounts for anthocyanins were very low, because of dilution by inner tissues.

Free sugars increased in both experiments during storage (Fig. $\mathrm{lb}$; Tables 3 and 4). This increase was delayed by the $\mathrm{Ca}$ treatments, in linear correlation with the $\mathrm{Ca}$ concentration. The effect of $\mathrm{Ca}$ was more striking at the end of storage.

Organic acids slowly decreased during storage and this decline was delayed by $\mathrm{Ca}$. The effect of $\mathrm{Ca}$ was noticeable after 10 days of storage and it was linearly correlated with $\mathrm{Ca}$ concentration at day 28, especially in Expt. 1 (Tables 3 and 4).

Electrical conductivity of the tissues increased rapidly between day 5 and 10 of storage for all treatments. After 10 days of storage, the increase was less noticeable with the Ca-treated strawberries, and at the end of storage, a linear correlation was observed between this increase and Ca concentration (Table 3 ). The significance of the interaction between rate of application . and storage indicated that tissue conductivity varied during storage, depending on dose of $\mathrm{CaCl}_{2}$ applied.

The force required to compress the berries decreased during storage. The lowest values were obtained with control fruit at the end of storage (Fig. 1c; Tables 3 and 4). The linear correlation between the delay in softening after $\mathrm{Ca}$ treatment and the dose applied was more significant in Expt. 1 than in 2. The dose of application $\mathrm{x}$ storage interaction was significant for tissue conductivity, which means that the change in texture during storage depended on $\mathrm{Ca}$ concentration.

Mold (Botrytis cinerea) was observed after 5 and 12 days in Expts. 1 and 2, respectively. Calcium treatment caused a delay in mold development, especially near the end of storage, and the response was linearly correlated with the rate of application. The dose of application $\mathrm{x}$ storage interaction was significant in both experiments (Tables 3 and 4). Eight and nine microorganisms were identified on the fruit at harvest in Expts. 1 and 2, respectively. Only Botrytis cinerea developed during storage at $4 \mathrm{C}$. 


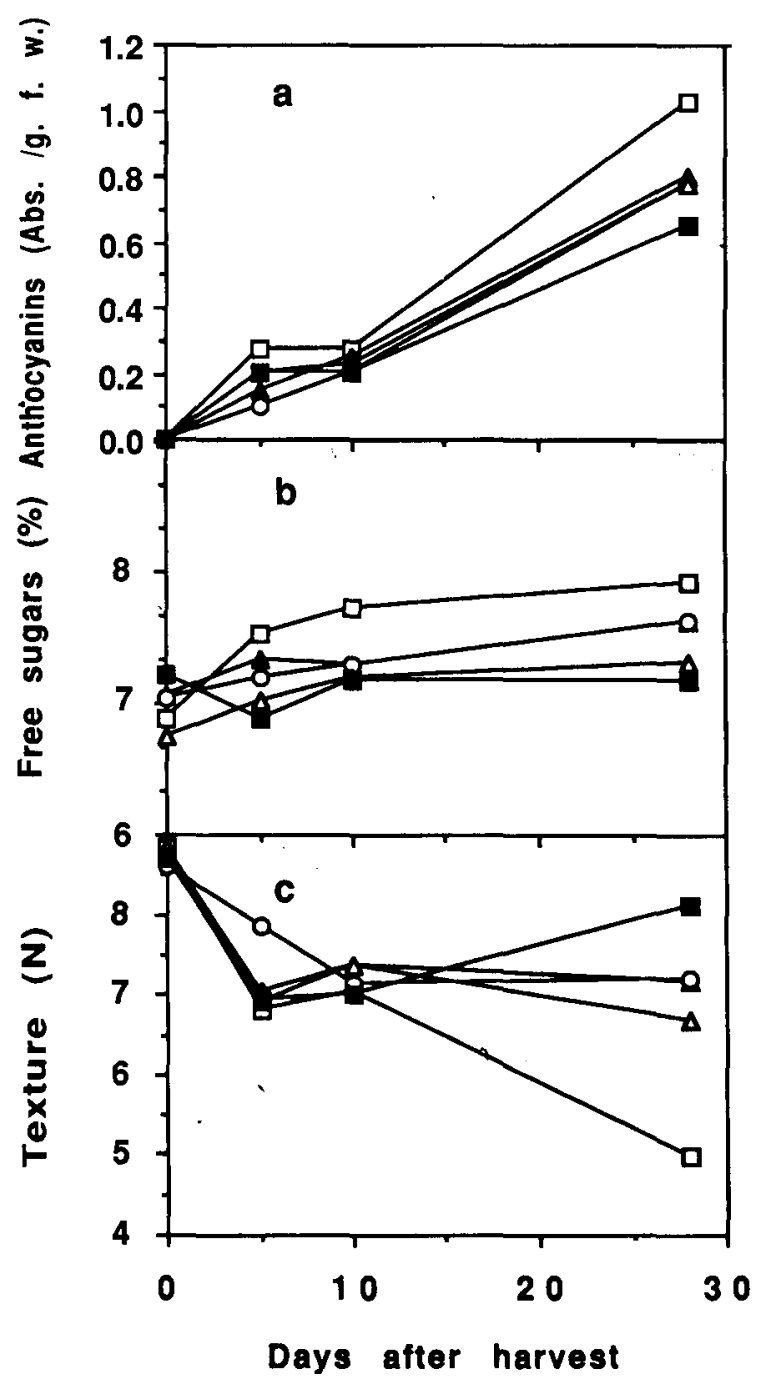

FIG. 1. Effect of foliar application of $\mathrm{CaCl}_{2}$ on (a) anthocyanin content (absorbance at $510 \mathrm{~nm} / \mathrm{gram}$ fresh weight), (b) free sugar content (percent fresh weight), and (c) texture $(\mathrm{N})$ of 'Kent' strawberries during storage at $4 \mathrm{C}$ (Expt. 1). Rate of application of $\mathrm{CaCl}_{2}\left(\mathrm{~kg} \cdot \mathrm{ha} \mathrm{s}^{-1}\right)$ : $0(\square), 5(\Delta), 10(\bigcirc), 15(\boldsymbol{\Delta}), 20(\boldsymbol{\square}) . \mathrm{SD}=0.05,0.16$, and 0.80 , respectively.

\section{Discussion}

The characteristic symptoms of ripening, increase in free sugars, anthocyanins, and tissue conductivity; mold development; and decrease in titratable acidity and firmness, were observed on the strawberries during storage. Foliar application of $\mathrm{CaCl}_{2}$ 3 to 9 days before harvest caused an increase in Ca content of the tissues, delayed ripening, and prolonged storage life; the visual appearance of the Ca-treated fruits, but not of the controls, was still acceptable at the end of storage. For most ripening characteristics, the effects of $\mathrm{Ca}$ were proportional to the rate of application (rate of application $\times$ storage interactions were often significant), which suggests a direct relationship between $\mathrm{Ca}$ content of the tissues and delay in ripening. The data concur with those of Eaves and Leefe (1962), who measured the effect of $\mathrm{Ca}$ on strawberry texture after storage. Similar effects have been observed with apple (Paliyath et al., 1984), pear (Richardson and Al-Alani, 1982), and avocado (Tingwa and Young, 1974). Calcium protects cellular organization (Jones and Lunt, 1970) and, in this way, prevents some physiological
Table 3. Probability level for maturity attributes of 'Kent' strawberries: anthocyanins (1), free sugars (2), titratable organic acids (3), texture (4), electrical conductivity (5), and visual evaluation (6). (Expt. 1)

\begin{tabular}{|c|c|c|c|c|c|c|}
\hline \multirow{2}{*}{$\begin{array}{l}\text { Source of } \\
\text { variation }\end{array}$} & \multicolumn{6}{|c|}{ Maturity attribute } \\
\hline & 1 & 2 & 3 & 4 & 5 & 6 \\
\hline Blocks & 0.047 & 0.046 & NS & NS & NS & NS \\
\hline Storage & 0.001 & 0.011 & 0.001 & 0.001 & 0.003 & 0.001 \\
\hline Rate of & & & & & & \\
\hline application & 0.011 & 0.008 & 0.014 & 0.001 & 0.030 & 0.001 \\
\hline Linear & 0.003 & 0.001 & 0.001 & 0.001 & 0.019 & 0.001 \\
\hline Rate $\times$ storage & NS & NS & NS & 0.001 & 0.005 & 0.001 \\
\hline $\begin{array}{l}\text { Rate } \times \text { time of } \\
\text { application }\end{array}$ & & & & & & \\
\hline$\times$ storage & NS & NS & 0.015 & 0.051 & NS & 0.011 \\
\hline Contrast & & & & & & \\
\hline $\begin{array}{l}\text { Control vs. } \\
\text { others }\end{array}$ & 0.001 & 0.004 & 0.014 & 0.001 & 0.002 & 0.001 \\
\hline
\end{tabular}

Table 4. Probability level for maturity attributes of 'Tribute' strawberries: free sugar (1), titratable organic acids (2), texture (3), and visual evaluation (4). (Expt. 2)

\begin{tabular}{lcccc}
\hline \hline \multirow{2}{*}{$\begin{array}{l}\text { Source of } \\
\text { variation }\end{array}$} & \multicolumn{4}{c}{ Maturity attribute } \\
\cline { 2 - 5 } & 1 & 2 & 3 & 4 \\
\hline Storage & 0.042 & 0.007 & 0.011 & 0.001 \\
Rate of application & 0.003 & 0.003 & 0.053 & 0.001 \\
Linear & 0.006 & 0.019 & 0.023 & 0.001 \\
Rate $\times$ storage & NS & NS & NS & 0.001 \\
Contrast & & & & \\
$\quad$ Control vs. others & 0.009 & 0.003 & 0.016 & 0.001 \\
\hline
\end{tabular}

disorders (Shear, 1975). Calcium may influence structure and function of the cell walls and membranes and certain aspects of cell metabolism (Glenn et al., 1988; Poovaiah, 1987). The delay in the progression of several signs of ripening, e.g., anthocy anin, free sugar, and organic acid contents, is evidence for the role of $\mathrm{Ca}$ in the regulation of cell biochemistry in strawberry.

The increase in tissue $\mathrm{Ca}$ content after treatment was not influenced by the degree of maturity at treatment or by the frequency of application. This lack of influence may be explained by the relative immobility of $\mathrm{Ca}$ in tissues (Hanger, 1979), known as a cause of the Ca deficiency often observed in leaves and fruits (Ferguson, 1984). The lack of influence of repeated applications in Expt. 2 with 'Tribute' and the less pronounced response to $\mathrm{Ca}$ application might be due to the higher $\mathrm{Ca}$ content of soil, leaves, and fruits in this experiment than in Expt. 1. Exogenous $\mathrm{Ca}$ will only bind to cellular sites if these sites are not saturated (Conway and Sams, 1987). Calcium treatment of strawberries may only be useful when Ca content of tissues is below a critical threshold. The difference in response to $\mathrm{Ca}$ application might also result from a difference in the ability of the cultivars to accumulate $\mathrm{Ca}^{++}$. The phytotoxic effects of repeated applications are apparently of little consequence (Bramlage et al., 1985).

Calcium levels in leaves and fruits were closely correlated, and Ca determination in leaves may serve to predict levels in fruits at harvest and to diagnose the need for treatment. Soil Ca level is not a reliable criterion because of the influence of factors such as temperature, humidity, plant age, cultivar, and, especially, the level of other minerals in the soil on uptake and translocation of $\mathrm{Ca}$ (Ferguson, 1984).

Although several fungi were identified on the strawberries at 
harvest, only Botrytis cinerea developed during storage at 4C. Botrytis grows at temperatures as low as - 4C (Sommer et al., 1973) and is a major limit to the storage life of strawberries. Calcium treatment delayed development of Botrytis and likely would reduce losses due to this pathogen.

In conclusion, the foliar application of $\mathrm{CaCl}_{2}$ led to increased $\mathrm{Ca}$ content of strawberry fruits and delayed ripening and mold development. Determination of leaf $\mathrm{Ca}$ content, closely correlated with fruit $\mathrm{Ca}$ content, may serve as an indicator of the need for $\mathrm{Ca}$ treatment.

\section{Literature Cited}

Ahmed, E.M. and R.A. Dennison. 1972. Textural properties of stored and irradiated Tioga strawberries. J. Texture Studies 3:80-88.

Anderson, V.L. and R.A. McLean. 1974. Design of experiments. Marcel Dekker, New York.

Bangerth, F., D.R. Dilley, and D.H. Dewey. 1972. Effect of postharvest calcium treatments on internal breakdown and respiration of apple fruits. J. Amer. Soc. Hort. Sci. 87:679-682.

Bramlage, W. G., M. Drake, and S.A. Weis. 1985. Comparison of calcium chloride, calcium phosphate, and a calcium chelate as foliar sprays for 'McIntosh' apple trees. J. Amer. Soc. Hort. Sci. 110:786789.

Conseil des Productions Végétales du Québec. 1982. Guide de recommandations de la culture des petits fruit. Ministère de l'Agriculture, des Pêcheries et de l'Alimentation du Québec.

Conway, W.S. and C.E. Sams. 1987. The effects of postharvest infiltration of calcium, magnesium, or strontium on decay, firmness, respiration, and ethylene production in apple. J. Amer. Soc. Hort. Sci. 112:300-303.

Eaves, C.A. and J.S. Leefe. 1962. Note on the influence of foliar sprays of calcium on the firmness of strawberries. Can. J. Plant Sci. 42:746-747.

El-Kazzaz, M. K., N.F. Sommer, and R.J. Fortlage. 1983. Effect of different atmospheres on postharvest decay and quality of fresh strawberries. Phytopathology 73 :282-285.

Ferguson, I.B. 1984. Calcium in plant senescence and fruit ripening. Plant Cell. Environ. 7:477-489.

Fuleki, T. and F.J. Francis. 1968. Quantitative methods for anthocyan ins. Determination of total anthocyanins and degradation index for cranberry juice. J. Food Sci.33:78-83.

Gaines, T.P. and G.A. Mitchel. 1979, Chemical methods for soil and plant analysis. Univ. of Georgia, Coastal Plain Expt. Sta. Agronomy Hdbk. 1.

Glenn, G. M., A.S. Reddy, and B.W. Poovaiah. 1988. Effect of calcium on wall structure, protein phosphorylation and protein profile in senescing apples. Plant Cell. Physiol. 29:565-572.

Hanger, B.C. 1979. The movement of calcium in plants. Commun. Soil Sci. Plant Anal. 10:171-193.

Jones, R.G. and O.R. Lunt. 1970. The function of calcium in plants. Bet. Rev. 35:407-426.

Maas, J.L. 1971. Timing of benomyl application in relation to control of Botrytis strawberry rot. Plant Dis. Rptr. 55:883-885.

Mehlich, A. 1984. Mehlich 3 soil test extractant: A modification of Mehlich 2 extractant. Commun. Soil Sci. Plant Anal. 15:1409-1416.

Morris, J. R., W.A. Sistrunk, C.A. Sims, G.L. Main, and E.J. Wehunt. 1985. Effects of cultivar, postharvest storage, preprocessing dip treatments and style of pack on the processing quality of strawberries. J.. Amer. Soc. Hort. Sci. 110:172-177.

Nirenberg, H.I. 1981. A simplified method for identifying Fusurium spp. occurring on wheat. Can. J. Bet. 59: 1599-1609.

Paliyath, G., B.W. Poovaiah, G.R. Munske, and J.A. Magnuson. 1984. Membrane fluidity in senescing apples: Effects of temperature and calcium. Plant Cell. Physiol. 25: 1083-1087.

Poovaiah, B.W. 1986. Role of calcium in prolonging storage life of fruits and vegetables. Food Tech. 40:86-89.

Poovaiah, B.W. 1987. The role of calcium and calmodulin in senescence, p. 182-189. In: W.W. Thomson, E.A. Nothnagel, and R.C. Huffaker (eds.). Plant senescence: Its biochemistry and physiology. Amer. Soc. Plant Physiol., Rockville, Md.

Poovaiah, B.W. and A.C. Leopold. 1973. Differal of leaf senescence with calcium. Plant Physiol. 52:236-239.

Richardson, D.G. and A.M. Al-Alani. 1982. Calcium and nitrogen effects on d'Anjou pear fruit respiration and ethylene evolution. Acta Hort. 124:195-201.

Shear, C.B. 1975. Calcium-related disorders of fruits and vegetables. HortScience 10:361-365.

Snedecor, G.W. and W.G. Cochran. 1957. Statistical methods. 6th ed. Iowa State Univ. Press, Ames.

Sommer, N. F., R.J. Fortlage, F.G. Mitchell, and E.C. Maxie. 1973. Reduction of postharvest loss of strawberry fruits from gray mold. J. Amer. Soc. Hort. Sci. 98:285-288.

Tingwa, P.O. and R.E. Young. 1974. The effect of calcium on the ripening of avocado (Persa americana Mill.) fruits. J. Amer. Soc. Hort. Sci. 99:540-542. 